\title{
KERAGAMAN KOMPOSISI JENIS DAN STRUKTUR VEGETASI PADA KAWASAN HUTAN LINDUNG DENGAN POLA PHBM DI BKPH TAMPOMAS, KPH SUMEDANG, PERUM PERHUTANI DIVISI REGIONAL JAWA BARAT DAN BANTEN
}

\author{
Species Composition and Vegetation Structure of Protected Forest Area using CBFM \\ (Community Based Forest Management) in BKPH Tampomas, FMU (Forest Management \\ Unit) Sumedang Perum Perhutani Regional Division of West Java and Banten Region
}

\section{Cecep Kusmana dan Anggun Rahayu Melyanti}

Departemen Silvikultur, Fakultas Kehutanan IPB

\begin{abstract}
BKPH Tampomas is part of the FMU area of Sumedang entirely classified into protected forest area. However, part of treated as CBFM with the aim of involfing the community in forest concervation activities the aim of this research is to describe and compare the structure and composition of the plant species between the subjected to CBFM and non CBFM Tampomas. The reaserch location was based on forest status of the protected area as having the same stand age and tree spacing. Data collection conducted throught the analysis of vegetation and soil sampling at each observation location species richness of BKPH Tampomas protection forest was relatively low either non CBFM of protected forest, CBFM protection forest of coffe and CBFM protection forest of cardamon. At the level of seedling stage there are 9 species and Calliandra haematocephala, the dominant. Species at the pole stage are found 3 species with Pinus merkusii species as the dominant species, at the tree stage are 2 species that dominated by Pinus merkusii. The covercrop found were 30 species and dominated by Lepturus repens. The low soil fertility and sandy soil texture composition also account for the low plant species in the BKPH Tampomas protection forest areas.
\end{abstract}

Key words : CBFM cardamon, CDFM coffee, species composition, structure vegetation, Tampomas Mountain

\section{PENDAHULUAN}

Hutan tropis Indonesia memiliki luas 126.09 juta ha (daratan dan perairan). Luasan hutan tersebut dikelompokkan ke dalam beberapa kelompok hutan yaitu, hutan lindung seluas 29.67 juta ha, hutan produksi terbatas 26.79 juta ha, hutan produksi tetap seluas 29.25 juta ha, dan hutan produksi yang dapat dikonversi seluas 12.94 juta ha (Kementerian LHK 2015). Setiap kelompok hutan di Indonesia umumnya memiliki keanekaragamanan hayati yang tinggi. Sehubungan dengan itu pengelolaan hutan harus dilakukan secara tepat agar keanekaragaman hayati yang tinggi tersebut tetap terjaga kelestariannya. Oleh karena itu, diperlukan suatu teknik terobosan untuk mendukung pengelolaan hutan yang tepat tersebut.

Saat ini pertumbuhan penduduk khususnya di Pulau Jawa tidak seimbang dengan persediaan lahan usaha yang tersedia, akibatnya areal hutan menjadi semakin sempit karena kebutuhan manusia akan lahan yang semakin meningkat. Kebutuhan tersebut tidak hanya untuk lahan pertanian, tetapi juga untuk perumahan, sektor industri, dan lainya. Hal ini di khawatirkan akan mengganggu ekosistem hutan yang ada di Pulau Jawa khususnya dan di wilayah Indonesia pada umumnya.
Perum Perhutani KPH Sumedang merupakan salah satu pengelola hutan di Pulau Jawa yang berada dalam lingkup Perusahaan Umum Kehutanan Negara (Perum Perhutani) Divisi Regional Jawa Barat dan Banten. Memiliki visi menjadi pengelola hutan lestari untuk sebesar-besarnya kemakmuran rakyat. Berkaitan dengan visi tersebut diperlukan suatu tindakan pengelolaan hutan yang dapat memakmurkan pula masyarakat di sekitar hutan. Namun kegiatan masyarakat dalam pemanfaatan sumberdaya hutan dikhawatirkan dapat mengganggu kelestarian hutan yang mengakibatkan kerusakan. Untuk menanggulangi permasalahan tersebut KPH Sumedang melaksanakan suatu program yang megikutsertakan masyarakat dalam kegiatan pengelolaan hutan melalui program PHBM (pengelolaan hutan bersama masyarakat). Berdasarkan keputusan Direksi Perhutani No : 268/KPTS/DIR/2007 tentang Pedoman Pengelolaan Sumberdaya Hutan Bersama Masyarakat Plus (PHBM Plus). PHBM Plus adalah suatu sistem pengelolaan sumberdaya hutan dengan pola kolaborasi antara Perum Perhutani dan masyarakat desa hutan atau para pihak yang berkepentingan dalam upaya mencapai keberlanjutan fungsi dan manfaat sumberdaya hutan yang optimal. Saat ini program tersebut diakui mampu mengurangi 
gangguan hutan yang terjadi di sekitar kawasan hutan Perhutani.

Belum diketahui dengan pasti dampak dari program ini terhadap komposisi jenis dan struktur vegetasi di kawasan hutan Perhutani itu sendiri. Untuk itu diperlukan suatu penelitan terkait kondisi vegetasi (komposisi jenis dan struktur vegetasi) dari hutan yang berdekatan dengan lokasi pelaksanaan program PHBM dan lokasi hutan yang berjauhan dengan lokasi pelaksanaan program PHBM.

\section{BAHAN DAN METODE}

\section{Waktu dan Tempat}

Penelitian ini dilaksanakan pada bulan Juli-Oktober 2015 di hutan lindung BKPH Tampomas yang terletak di KPH Sumedang, Perum Perhutani Divisi Regional Jawa Barat dan Banten (107 $14^{\circ}$ ' BT sampai dengan $108^{\circ} 21^{\prime \prime}$ BT dan $60^{\circ} 40^{\prime}$ LS sampai dengan $70^{\circ} 83^{\prime}$ LS). Secara administrasi, lokasi penelitian berada di tiga desa yaitu Desa Cimala, Desa Tanjungkerta, dan Desa Narimbang.

Luas kawasan KPH Sumedang mencapai 37572.63 ha. Adapun jenis tanah di Gunung Tampomas adalah andosol coklat kekuningan dari bahan induk abu pasir volkan intermedier basis dan fisiografi volka. Gunung Tampomas temasuk ke dalam tipe iklim hujan $\mathrm{C}$ dengan curah hujan rata-rata $3158 \mathrm{~mm}$ per tahun.

Berdasarkan hasil inventarisasi biodiversitas KPH Sumedang pada tahun 2012 ditemukan jenis aves 41 spesies, amfibi 5 spesies, reptile 10 spesies dan mamalia 5 spesies. Jenis pohon yang mendominasi kawasan KPH meliputi Pinus merkusii dan jenis rimba campuran meliputi mahoni, kaliandra, dan jenis tanaman buah. Gunung Tampomas juga memiliki beberapa satwa endemik yang dilindungi, diantaranya elang jawa (Spizaetus bartelsi). Pada tahun 1998 telah dipublikasikan perjumpaan dengan 7 individu elang Jawa di Puncak-Manik dan Puncak Narimbang (Setiadi 2000). Jenis burung lain yang ditemukan, diantaranya: puyuh gonggong jawa, dan takur tohtor. Selain itu, macan tutu1 (Pantera pardzis) dan beberapa anggota keluarga primata seperti kera (Macaca fascicularis) dan lutung (Presbytis cristata).

\section{Alat dan Bahan}

Alat dan bahan yang digunakan dalam penelitian ini yaitu; peta petak kerja, alat tulis, tallysheet, patok, pita ukur/phiband, kompas, GPS, golok, haga, buku identifikasi, oven, sasak, skop kecil, ring sampel, ring master, papan penekan, plastik, label, pisau, kamera, dan Ms Office 2013. Adapun bahan yang digunakan, yaitu; label, tali tambang/rafia, kantung plastik, kertas koran, alkohol, dan kertas karton.

\section{Metode Penelitian}

\section{Persiapan}

Tahapan persiapan kegiatan meliputi beberapa kegiatan diantaranya survei lokasi penelitian, pengurusan izin administrasi pada instansi terkait, pengumpulan data sekunder/literatur terkait dengan penelitian serta persiapan peralatan dan bahan pengambilan data lapang.

\section{Penentuan Lokasi Penelitian}

Penentuan lokasi penelitian didasarkan pada tipe hutan yang akan diteliti, yaitu hutan dengan status kawasan hutan lindung dan umur tegakannya sama, serta jarak tanam yang sama. Selain itu penetuan lokasi juga didasarkan pada perilaku pengelolaan lahan yang diberikan pada lokasi tersebut, yaitu hutan lindung murni dan hutan lindung dengan perlakuan penerapan program PHBM.

\section{Analisis Vegetasi}

Pengambilan data lapangan dilakukan dengan teknik analisis vegetasi berupa petak tunggal dengan luas masing-masing petak adalah $30 \mathrm{~m}$ x $30 \mathrm{~m}$ berbentuk bujur sangkar yang kemudian dibagi menjadi beberapa ukuran sub-petak contoh. Secara rinci ukuran sub petak contoh tersebut adalah:

1. Ukuran $10 \mathrm{~m}$ x $10 \mathrm{~m}$ digunakan untuk merisalah pertumbuhan pada tingkat pohon dan tiang. Data yang diambil berupa jenis, jumlah individu, diameter batang dan tinggi pohon.

2. Ukuran $5 \mathrm{~m} \times 5 \mathrm{~m}$ digunakan untuk merisalah pertumbuhan pada tingkat pancang, jenis palem dan pandan. Data yang dikumpulkan meliputi jenis dan jumlah individu.

3. Ukuran $2 \mathrm{~m} \times 2 \mathrm{~m}$ digunakan untuk merisalah pertumbuhan semai, tumbuhan bawah, semak dan herba dengan data yang dikumpulkan meliputi jenis dan jumlah individu.

Satu buah petak ditempatkan secara purposive pada masing-masing lokasi penelitian (hutan lindung murni, hutan lindung PHBM kopi, dan hutan lindung PHBM kapolaga).

\section{Pengambilan Contoh Tanah}

Tahapan pengambilan contoh tanah tidak terganggu menurut (Purwowidodo 2004), adalah sebagai berikut :

1. Membersihkan permukaan tanah dari ranting, rumput atau kotoran lainnya, lalu meletakkan ring sampel di atas tanah.

2. Menekan ring sampel menggunakan penekan, kemudian pukul penekan menggunakan palu sampai tiga perempat badan ring sampel masuk ke tanah.

3. Meletakkan (sambungkan) ring master di atas ring sampel.

4. Memukul penekan menggunakan palu hingga sebagian ring master masuk ke dalam tanah.

5. Menggali tanah di sekitar ring, kemudian ambil ring sampel dengan menggunakan pisau atau skop. Kemudian meratakan permukaan ring dengan pisau lalu tutup. 
Pengambilan contoh tanah tidak terganggu pada masing-masing lokasi penelitian dilakukan pada 6 titik, yaitu 4 di sudut dan 2 di tengah petak analisis vegetasi. Selanjutnya pengambil contoh tanah terganggu (tanah komposit) dilakukan dengan menggunakan metode zigzag atau acak dalam satu petak contoh analisis vegetasi. Adapun sifat fisik dan kimia tanah yang dianalisis diantaranya tekstur, permeabilitas, bulk density, $\mathrm{pH}, \mathrm{C}$ organik, N-total, P, dan $\mathrm{K}$.

\section{Analisis Data}

Data lapang diolah untuk menghitung Indeks Nilai Penting (INP), Indeks Dominansi Jenis (C), Indeks Keanekaragaman Jenis (H'), Indeks Kemeratan jenis (E), Indeks Kekayaan Jenis (R), dan Indeks Kesamaan Komunitas (IS). Analisis tanah dilakukan di Laboratorium Manajemen Sumberdaya Lahan Fakultas Pertanian IPB dan Laboratorium Pengaruh Hutan Fakultas Kehutanan IPB, yang dilaksanakan dari bulan Agustus - Okober 2015.

\section{HASIL DAN PEMBAHASAN}

\section{Hasil}

Berdasarkan pengamatan ditemukan 30 jenis tumbuhan bawah, 9 jenis semai, 3 jenis tiang, dan 2 jenis pohon. Hasil analisis vegetasi yang telah dilakukan pada berbagai tingkat pertumbuhan dan tumbuhan bawah di lokasi pengamatan dapat dilihat pada Gambar 1.

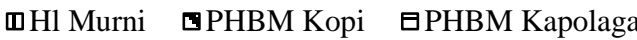

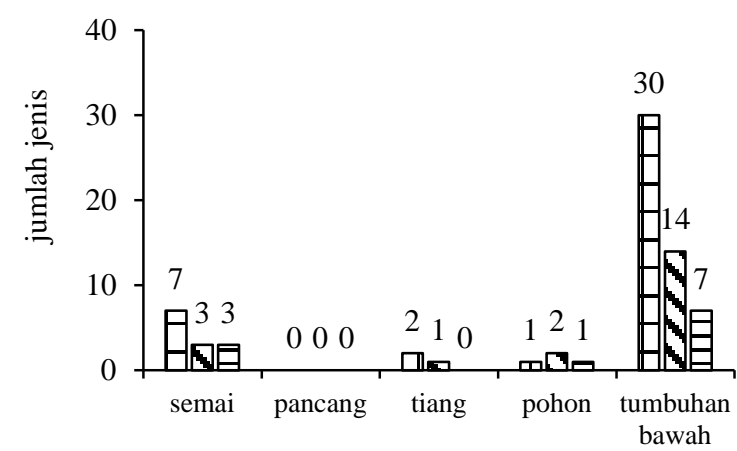

Gambar 1 Jumlah jenis tumbuhan pada berbagai tingkat pertumbuhan di BKPH Tampomas

Hutan lindung murni memiliki jumlah jenis tumbuhan paling tinggi dibandingkan dengan petak PHBM. Jumlah jenis tumbuhan erat kaitannya dengan nilai indeks kekayaan jenis (R). Tabel 1 menyajikan data hasil perhitungan nilai $\mathrm{R}$ pada seluruh petak pengamatan. Berdasarkan data pada Tabel 1, indeks kekayaan jenis pada tingkat semai, tiang dan pohon memiliki nilai indek kekayaan jenis yang rendah.
Tabel 1 Indek kekayaan jenis (R) tumbuhan di kawasan hutan lindung BKPH Tampomas

\begin{tabular}{ccccc}
\hline Tingkat & \multicolumn{3}{c}{ Indeks Kekayaan Jenis (R) } & Keterangan \\
\cline { 2 - 4 } Pertumbuhan & $\begin{array}{c}\text { HL } \\
\text { Murni }\end{array}$ & $\begin{array}{c}\text { PHBM } \\
\text { Kopi }\end{array}$ & $\begin{array}{c}\text { PHBM } \\
\text { Kapolaga }\end{array}$ & \\
\hline Semai & 0.93 & 0.61 & 0.41 & Rendah \\
Pancang & - & - & - & Rendah \\
Tiang & 0.35 & - & - & Rendah \\
Pohon & - & 0.18 & - & Rendah \\
Tumbuhan & 3.42 & 2.03 & 1.40 & Rendah \\
Bawah & & &
\end{tabular}

Ket: HL. Murni=Hutan Lindung Murni; PHBM Kopi=Hutan Lindung dengan PHBM Kopi; PHBM Kapolaga=Hutan Lindung dengan PHBM Kapolaga

Indeks nilai penting (INP) digunakan untuk menganalisis dominansi suatu jenis dalam komunitas tertentu. Pada tingkat pertumbuhan semai Caliandra haematocephala Hassk menjadi jenis dominan di semua petak pengamatan. Adapun untuk jenis Swietenia mahagoni dan Persea americana merupakan jenis kodominan untuk petak pengamatan PHBM kopi dan kapolaga. Pada tumbuhan bawah jenis Altaernathera brasiliana dan Cryperis rotundus merupakan jenis dominan dan kodominan di hutan lindung murni dan hutan lindung PHBM kopi. Semantara itu di petak hutan lindung dengan PHBM kapolaga jenis dominan dan kodominannya adalah $C$. rotundus dan Eragrogstis amabilis. Tingkat pertumbuhan pancang tidak ditemukan pada seluruh petak pengamatan. Adapun tingkat pohon dan tiang pada kawasan hutan lindung BKPH Tampomas ditemukan pada petak pengamatan hutan lindung murni. Tingkat pertumbuhan tiang hanya ditemukan pada petak pengamatan hutan lindung murni dan hutan lindung dengan perlakukan PHBM kopi. Pada tingkat tiang ditemukan tiga jenis pohon, yaitu $P$. merkusii, Mangifera indica, S. mahagoni. Untuk tingkat pertumbuhan pohon dapat ditemukan pada seluruh petak pengamatan yang terdiri dari dua jenis, yaitu $P$. merkusii dan S. mahagoni.

\section{Indeks dominansi jenis (C)}

Tabel indeks dominansi jenis (C) pada kawasan hutan lindung di BKPH Tampomas disajikan pada Tabel 5. Berdasarkan data pada Tabel 5, di lokasi penelitian pada semua tingkat pertumbuhan hampir tidak terjadi pemusatan atau pengelompokan suatu jenis, kecuali pada tingkat pertumbuhan tiang di hutan lindung murni dan hutan lindung dengan perlakuan PHBM kopi.

Tabel 5 Indeks dominansi jenis (C) pada kawasan hutan lindung di BKPH Tampomas

\begin{tabular}{cccccc}
\hline \multirow{2}{*}{ Lokasi } & \multicolumn{3}{c}{ Tingkat pertumbuhan } & \multirow{2}{*}{ Tumbuhan } \\
\cline { 2 - 5 } & Semai & Pancang & Tiang & Pohon & bawah \\
\hline $\begin{array}{c}\text { HL } \\
\text { Murni }\end{array}$ & 0.19 & - & 0.86 & 0.33 & 0.03 \\
$\begin{array}{c}\text { PHBM } \\
\text { Kopi }\end{array}$ & 0.32 & - & 1.00 & 0.31 & 0.07 \\
$\begin{array}{c}\text { PHBM } \\
\text { Kapolaga }\end{array}$ & 0.26 & - & - & 0.33 & 0.08
\end{tabular}

Ket; HL. Murni = Hutan Lindung Murni; PHBM Kopi = Hutan Lindung dengan PHBM Kopi; PHBM Kapolaga $=$ Hutan Lindung dengan PHBM Kapolaga. 


\section{Indeks keanekaragaman jenis (H')}

Indeks kekanekaragaman jenis merupakan suatu nilai yang menunjukan keberagaman jenis yang ditemukan pada lokasi penelitian. Data hasil perhitungan nilai indeks keanekaragaman jenis (H') di lokasi penelitian dapat dilihat pada Tabel 6 .

Tabel 6 Indeks Keanekaragaman jenis $\left(\mathrm{H}^{\prime}\right)$ pada kawasan hutan lindung di BKPH Tampomas.

\begin{tabular}{cccccc}
\hline Lokasi & \multicolumn{3}{c}{ Tingkat pertumbuhan } & Tumbuhan \\
\cline { 2 - 5 } & Semai & Pancang & Tiang & Pohon & bawah \\
\hline HL Murni & 0.32 & - & 0.13 & 0.36 & 0.37 \\
PHBM Kopi & 0.36 & - & - & 0.36 & 0.20 \\
PHBM & 0.35 & - & - & 0.36 & 0.12 \\
Kapolaga & & & & & \\
\hline
\end{tabular}

Ket: HL. Murni $=$ Hutan Lindung Murni; PHBM Kopi $=$ Hutan Lindung dengan PHBM Kopi; PHBM Kapolaga = Hutan Lindung dengan PHBM Kapolaga.

Umumnya keanekaragaman jenis tumbuhan pada seluruh tingkat pertumbuhan di berbagai lokasi pengamatan termasuk ke dalam kategori rendah, dimana setiap lokasi indeks keanekaragaman jenisnya menunjukan nilai yang lebih kecil dari $2\left(\mathrm{H}^{\prime}<2\right)$.

\section{Indeks kemerataan jenis (E)}

Nilai indeks kemerataan jenis menunjukkan tingkat kemerataan suatu individu perjenis dalam luasan hutan tertentu. Data hasil perhitungan nilai indeks kemerataan jenis (E) di lokasi penelitian dapat dilihat pada Tabel 7.

Tabel 7 Indeks kemerataan jenis (E) pada kawasan hutan lindung di BKPH Tampomas.

\begin{tabular}{cccccc}
\hline Lokasi & \multicolumn{3}{c}{ Tingkat pertumbuhan } & Tumbuhan \\
\cline { 2 - 5 } & Semai & Pancang & Tiang & Pohon & bawah \\
\hline HL Murni & 0.16 & - & 0.19 & - & 0.11 \\
PHBM Kopi & 0.26 & - & - & 0.52 & 0.07 \\
PHBM & 0.31 & - & - & - & 0.05 \\
Kapolaga & & & & &
\end{tabular}

Ket: HL. Murni $=$ Hutan Lindung Murni; PHBM Kopi = Hutan Lindung dengan PHBM Kopi; PHBM Kapolaga = Hutan Lindung dengan PHBM Kapolaga.

Hasil perhitungan menunjukkan bahwa nilai E pada setiap tingkat pertumbuhan pada berbagai petak pengamatan memiliki nilai yang tergolong rendah. Hanya pada petak PHBM kopi, tingkat pertumbuhan pohon memiliki nilai $\mathrm{E}$ yang tergolong sedang $(\mathrm{E}=$ $0.52)$.

\section{Indeks kesamaan komunitas (IS)}

Data hasil perhitungan IS pada berbagai tingkat pertumbuhan disajikan pada Tabel 8 . Vegetasi hutan pada berbagai petak pengamatan di hutan lindung murni dan hutan lindung dengan perlakuan PHBM memiliki komunitas tumbuhan yang hampir sama, kecuali tingkat pertumbuhan pohon antara hutan lindung murni dan hutan lindung dengan perlakuan PHBM kapolaga yang relatif berbeda komposisi jenisnya. Pada tingkat pertumbuhan tiang dan pancang, tidak dapat dibandingkan dengan kondisi petak contoh yang lain, karena pada lokasi lainnya tidak dijumpai tumbuhantumbuhan kategori tingkat tiang dan pancang tersebut.
Tabel 8 Indeks kesamaan komunitas (IS) di hutan lindung BKPH Tampomas.

\begin{tabular}{|c|c|c|c|}
\hline $\begin{array}{c}\text { Tingkat } \\
\text { pertumbuhan }\end{array}$ & Lokasi & $\begin{array}{c}\text { PHBM } \\
\text { Kopi } \\
(\%)\end{array}$ & $\begin{array}{c}\text { PHBM } \\
\text { Kapolaga } \\
(\%)\end{array}$ \\
\hline \multirow[t]{2}{*}{ Semai } & $\begin{array}{c}\mathrm{HL} \\
\text { murni }\end{array}$ & 48.28 & 45.77 \\
\hline & $\begin{array}{l}\text { PHBM } \\
\text { kopi }\end{array}$ & 0.00 & 60.34 \\
\hline \multirow[t]{2}{*}{ Tiang } & $\begin{array}{c}\text { HL } \\
\text { murni }\end{array}$ & 10.95 & 0.00 \\
\hline & $\begin{array}{l}\text { PHBM } \\
\text { kopi }\end{array}$ & & 0.00 \\
\hline \multirow[t]{2}{*}{ Pohon } & $\begin{array}{l}\mathrm{HL} \\
\text { murni }\end{array}$ & 63.23 & 100.00 \\
\hline & $\begin{array}{c}\text { PHBM } \\
\text { kopi }\end{array}$ & 0.00 & 29.01 \\
\hline \multirow[t]{2}{*}{ Tumbuhan bawah } & $\begin{array}{l}\text { HL } \\
\text { murni }\end{array}$ & 31.91 & 51.49 \\
\hline & $\begin{array}{l}\text { PHBM } \\
\text { kopi }\end{array}$ & 0.00 & 67.33 \\
\hline
\end{tabular}

Ket: HL. Murni = Hutan Lindung Murni; PHBM Kopi = Hutan Lindung dengan PHBM Kopi; PHBM Kapolaga = Hutan Lindung dengan PHBM Kapolaga

\section{Struktur Horizontal}

Struktur tegakan dapat dilihat secara kumulatif pada hasil perhitungan kerapatan pada kelas diameter pohon pada suatu komunitas. Gambar 2 menunjukkan nilai struktur horizontal untuk setiap tingkat pertumbuhan.

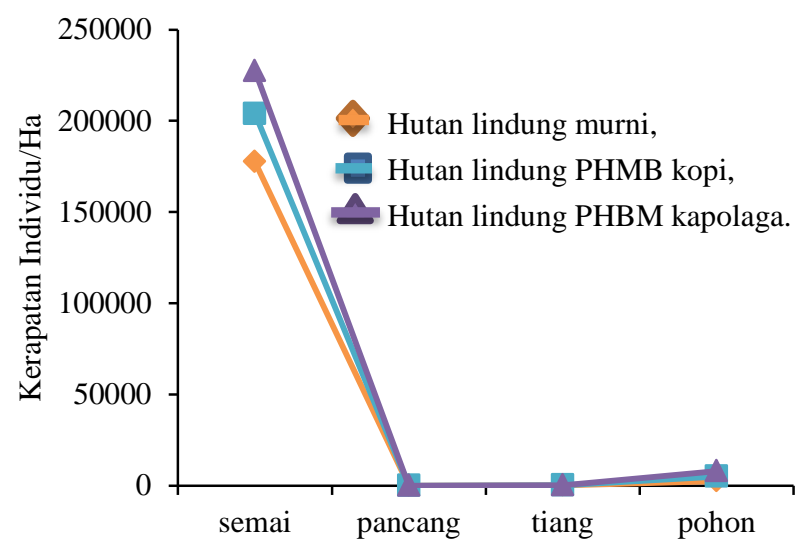

Gambar 2 Kerapatan individu pada berbagai tingkat pertumbuhan di hutan lindung di BKPH Tampomas.

Berdasarkan data pada Gambar 2, hutan lindung murni memiliki nilai pertumbuhan semai dan pohon yang lebih tinggi dibandingkan dengan hutan lindung dengan perlakuan PHBM kopi dan PHBM kapolaga.

\section{Startifikasi Tajuk}

Struktur tegakan vertikal (stratifikasi tajuk) pohon untuk semua jenis tumbuhan yang menghubungkan antara kerapatan pohon dengan kelas tinggi (stratum) tajuk dapat dilihat pada Gambar 3. Gambar 3 menunjukkan bahwa pohon terbanyak dijumpai pada kelas tinggi 4-20 meter (stratum C), kemudian kelas tinggi 20-30 meter (stratum B). Seluruh lokasi 
pengamatan berada pada ketinggian atara 700-876 mdpl dan berada pada kemiringan berkisar antara 40-50 derajat. Lantai hutan pada petak hutan lindung dengan PHBM Kapolaga hampir seluruhnya tertutupi oleh tanaman kapolaga dengan tinggi rata-rata mencai 120 $\mathrm{cm}$. Hal ini menyebabkan cahanya matahari sulit menembus hingga ke lantai hutan.

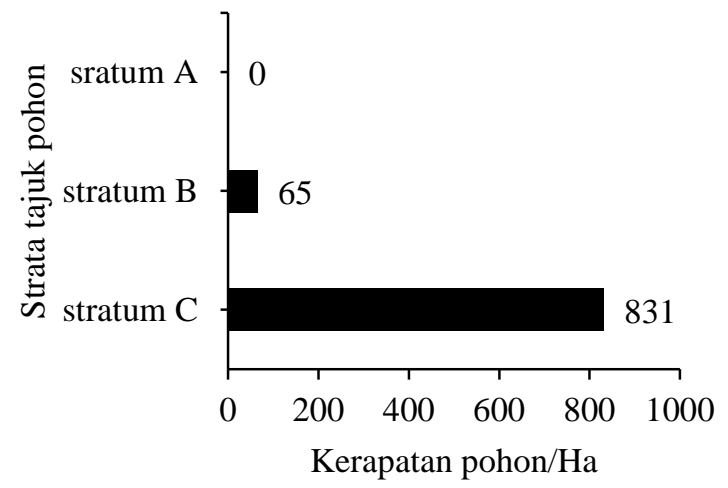

Gambar 3 Struktur vertikal hutan lindung di BKPH Tampomas.

\section{Hasil Analisis Tanah}

Kondisi tanah di wilayah BKPH Tampomas bertekstur kasar dengan dominasi pasir yang cukup tinggi sehingga dapat digolongkan ke dalam jenis tanah berpasir. Selain itu $\mathrm{pH}$ tanah pada seluruh lokasi penelitian juga tergolong masam (4.6-5.5). Hal ini di duga menjadi penyebab jumlah jenis tumbuhan yang mampu tumbuh di lokasi tersebut menjadi terbatas. Secara umum lokasi petak contoh memiliki kandungan unsur hara yang relatif rendah dengan persentase jumlah N-total (0.39-0.54\%) dan Fospor (9.7-11.67 ppm) yang sangat rendah hingga rendah, namun kandungan Kalium (129.67-383.21 ppm) pada seluruh lokasi sangat tinggi. Hutan lindung murni memiliki persentase jumlah Corganik $(3.1 \%)$ sedikit lebih tinggi dibandingkan dengan hutan lindung dengan perlakuan PHBM (4.3- 5.3\%).

Hasil analisis terkait permeabilitas dan bulk density tanah pada seluruh petak pengamatan menunjukkan hasil bahwa seluruh petak memiliki nilai permeabilitas tanah $(0.41-0.71 \mathrm{~cm} / \mathrm{jam})$ yang rendah dengan nilai BD (1.16-1.47 $\left.\mathrm{g} / \mathrm{cm}^{3}\right)$ yang tinggi, dengan kata lain penyerapan air ke dalam tanah cenderung lebih lambat akibat adanya pemadatan tanah.

\section{Pembahasan}

Hutan lindung adalah kawasan hutan yang mempunyai fungsi pokok sebagai perlindungan sistem penyangga kehidupan untuk mengatur tata air, mencegah banjir, mengendalikan erosi, mencegah intrusi air laut, dan memelihara kesuburan tanah (UU Kehutanan no 41. 1999). Kawasan hutan yang ada di wilayah BKPH Tampomas termasuk kedalam kawasan hutan lindung sejak tahun 1998 melalui kegiatan rescoring penetapan fungsi kawasan hutan. Adapun sebelum tahun 1998, 87\% kawasan BKPH Tampomas berfungsi sebagai hutan produksi terbatas dengan komoditas produksi berupa sadapan getah pinus (Zulkarnain 2013).

Berdasarkan hasil pengamatan didapatkan informasi bahwa jumlah jenis tumbuhan pada tingkat semai tergolong rendah, bahkan pada tingkat pertumbuhan pancang tidak ditemukan satupun jenis tumbuhan. Tidak jauh berbeda dengan tingkat pertumbuhan tiang dan pohon, pada setiap petak contoh hanya terdapat dua jenis spesies pada setiap tingkat pertumbuhannya. Adapun untuk tumbuhan bawah jumlah jenisnya 30 jenis.

Jenis tumbuhan yang ditemukan pada tingkat pertumbuhan pohon adalah $P$. merkusii dan $S$. mahagoni. Adapun pada tingkat pertumbuhan pancang tidak ditemukan satu individupun pada seluruh petak contoh. Pada tingkat pertumbuhan semai ditemukan 9 jenis individu tumbuhan. $C$. haematocephala atau kaliandra putih merupakan jenis semai yang paling dominan dan menyebar di seluruh petak contoh. Gopal dan Bhardwaj (1979) dalam Indriyanto (2008) menjelaskan bahwa suksesi sekunder terjadi pada lahan yang pada awalnya bervegetasi lengkap namun mengalami kerusakan akibat bencana atau manusia dan sebagainya. Adanya peningkatan jumlah jenis sampai tahap tertentu dalam proses suksesi vegetasi merupakan salah satu ciri suksesi tersebut. Kondisi ini semakin diperjelas dengan jumlah jenis tumbuhan bawah yang tinggi pada petak contoh hutan lindung murni, sehingga dapat dikatakan hutan lindung BKPH Tampomas saat ini sedang mengalami proses suksesi sekunder. Kawasan hutan lindung BKPH Tampomas didominasi oleh semai $C$. haematocephala dan L. leucocephala yang keduanya tergolong pada jenis tumbuhan pionir, meskipun demikian pada tahap akhir proses suksesi belum tentu jenis pionir ini akan menjadi jenis penting karena kondisi lingkungan yang klimaks belum tentu cocok dengan jenis tersebut. Tingkat pertumbuhan pohon hanya didominasi oleh satu jenis tumbuhan saja yaitu jenis $P$. merkusii, sedang pada tingkat tiang ditemukan tiga jenis tumbuhan yaitu $P$. merkusii, $S$. mahagoni dan Mangifera indica. Biodiversitas atau yang biasa dikenal dengan istilah keanekaragaman hayati terdiri atas tiga komponen yaitu kekayaan jenis (R), keanekaragaman jenis ( $\left.\mathrm{H}^{\prime}\right)$ dan kemerataan jenis (E) (Magurran 1988). Hasil perhitungan indeks kekayaan jenis (R) yang umumnya bernilai rendah pada tingkat tiang dan pohon, tetapi bernilai sedang pada tingkat semai dan bernilai tinggi pada tumbuhan bawah. Indeks keragaman jenis ( $\left.\mathrm{H}^{\prime}\right)$ menunjukkan bahwa kekayaan jenis tergolong rendah pada setiap tingkat pertumbuhan di seluruh petak pengamatan. Hasil perhitungan indeks kemerataan jenis (E) pada petak pengamatan PHBM kopi terlihat bahwa tingkat pertumbuhan pohon memiliki nilai indeks kemerataan jenis yang tergolong sedang, sedangkan pada petak pengamatan yang lain dengan tingkat pertumbuhan yang berbeda memiliki nilai indeks kemerataan jenis yang tergolong rendah.

Gambar 2 menyajikan hasil perhitungan kerapatan individu pada seluruh petak pengamatan yang membentuk huruf $\mathbf{J}$ terbalik, karena jumlah jenis individu pada tingkat permudaan lebih besar dibandingkan dengan jumlah jenis individu pada tingkat 
pertumbuhan tiang dan pohon. Stratifikasi tajuk merupakan cara untuk menjelaskan struktur vegetasi secara vertikal dalam suatu komunitas tumbuhan pada ekosistem tertentu. Berdasarkan hasil pengamatan dilapang pada hutan lindung BKPH Tampomas terdapat 2 strata pohon, yaitu strata B dan strata C.

Secara umum keanekaragaman hayati pada kawasan hutan lindung BKPH Tampomas umumnya memiliki kekayaan jenis dan keanekaragaman jenis tingkat pohon dan tiang yang rendah dengan kemerataan jenis yang tinggi pada petak pengamatan PHBM kopi. Keanekaragaman dan kemerataan tingkat semai dan tumbuhan bawah yang relatif tinggi mengindikasikan adanya perkembangan kearah pemulihan kawasan yang rusak. Indeks kesamaan komunitas (IS) vegetasi hutan untuk tingkat pertumbuhan pohon di kawasan hutan lindung BKPH Tampomas mempunyai komunitas tumbuhan yang hampir sama pada setiap petaknya, sedangkan pada tingkat pertumbuhan tiang dan pancang, tidak dapat dibandingkan dengan kondisi petak contoh yang lain, karena pada lokasi lainnya tidak dijumpai pertumbuhan tingkat tiang dan pancang. Hutan lindung murni memiliki jumlah jenis tumbuhan bawah dan semai lebih banyak dibandingkan dengan petak contoh yang diberi perlakuan PHBM kopi dan PHBM kapolaga. Pada petak contoh hutan lindung dengan PHBM kopi dan kapolaga jumlah jenisnya jauh lebih rendah dibandingkan dengan petak contoh hutan lindung murni. Keanekaragaman hayati yang ada di BKPH Tampomas dapat digolongkan ke dalam kategori rendah jika dibandingkan dengan kondisi hutan lindung di kawasan perhutani yang lain, seperti pada lokasi hutan lindung di KPH Garut keanekragaman tumbuhannya relatif lebih tinggi dibandingkan dengan BKPH Tampomas (KPH Garut 2004).

Berdasarkan data yang diperoleh pada petak hutan lindung murni maupun hutan lindung dengan perlakuan PHBM semua memiliki tingkat kekayaan jenis, dominasi jenis, keanekaragaman, dan kemerataan jenis yang rendah. Kondisi kesuburan tanah pada ke tiga lokasi tersebut menunjukkan hasil bahwa seluruh petak memiliki tingkat kesuburan tanah yang rendah dengan pH berkisar antara 4.6-5.5 (masam). Menurut Ali (2005) tanah yang masam akan menghambat penghancuran bahan organik, sedangkan bahan organik sangat dibutuhkan tumbuhan dalam proses pertumbuhannya.

Data unsur hara tanah yang terdapat pada seluruh petak contoh menunjukkan bahwa seluruh lokasi penelitian memiliki jumlah C-organik, Nitrogen (N) dan Fosfor $(\mathrm{P})$ yang tergolong sangat rendah. Kekurangan unsur hara dapat menghambat pertumbuhan tanaman. Adapun menurut Kurniawan dan Parikesit (2008), kandungan hara dan unsur kimia tanah, kemasaman (pH) tanah, batuan induk serta topografi memegang peran penting dalam penyebaran jenis tumbuhan.

Permeabilitas yang rendah juga mengakibatkan unsur hara yang ada di dalam tanah mudah sekali tercuci air hujan. Nilai bulk density yang tinggi mengindikasikan adanya pemadatan tanah yang membuat air serta oksigen sulit masuk ke dalam tanah (Edward et al. 2011).

\section{SIMPULAN DAN SARAN}

\section{Simpulan}

Jumlah jenis pada vegetasi hutan lindung BKPH Tampomas tergolong rendah, baik pada petak hutan lindung murni, hutan lindung PHBM Kopi maupun hutan lindung dengan PHBM Kapolaga. Pada tingkat pertumbuhan semai terdapat 9 spesies dan spesies yang mendominasi adalah $C$. haematocephala, pada tingkat pertumbuhan tiang ditemukan 3 spesies dengan $P$. merkusii sebagai spesies dominan, pada tingkat pertumbuhan pohon hanya 2 spesies yang di dominasi oleh P. merkusii. Adapun untuk tumbuhan bawah ditemukan 30 jenis dan didominasi oleh jenis Lepturus repens. Struktur vertikal hutan vegetasi tingkat pohon di BKPH Tampomas terdiri atas 2 strata yaitu strata B, strata C. Struktur horizontal vegetasi hutan cenderung membentuk kurva huruf $\mathrm{J}$ terbalik, hal ini menunjukkan proses suksesi sekunder yang berjalan baik seiring dengan pertambahan waktu. Kesuburan tanah yang rendah dan tekstur tanah yang berpasir juga menjadi penyebab rendahnya jumlah jenis tumbuhan yang ada di kawasan hutan lindung BKPH Tampomas. Selain itu, lokasi BKPH Tampomas yang seluruh kawasannya berbatasan langsung dengan pemukiman masyarakat membuat kawasan hutan ini sangat mudah terganggu dan mudah di akses oleh masyarakat.

\section{Saran}

Perlu diterapkannya teknik silvikultur dan penelitian mengenai jenis tanaman yang cocok dengan kondisi tanah dan hutan yang ada di BKPH Tampomas. Selain itu juga jenis tanamannya harus menguntungkan secara ekonomis bagi masyarakat agar pemanfaatan secara tidak terkendali terhadap hutan dapat dihindari.

\section{DAFTAR PUSTAKA}

Ali K. 2005. Dasar-dasar Ilmu Tanah. Jakarta (ID) : PT Raja Grafindo Persada.

Edward E, Hamidy R, Siregar SH. 2011. Komposisi dan struktur permudaan pohon pionir berdasarkan jenis tanah. Jurnal Ilmu Lingkungan 5 (2) : 149-167.

Indriyanto. 2008. Ekologi Hutan. Jakarta (ID): PT. Bumi Aksara.

[Kementerian LHK] Kementerian Lingkungan Hidup dan Kehutanan RI. 2015. Luas Kawasan Hutan dan Kawasan Konservasi Perairan Indonesia Menurut Provinsi Berdasarkan SK Menteri Kehutanan. Jakarta: Statistik Kementerian Lingkungan Hidup dan Kehutanan.

Kurniawan A, Parikesit. 2008. Persebaran jenis pohon di sepanjang faktor lingkungan di Cagar Alam Pananjung Pangandaran, Jawa Barat. Biodiversitas. 9 (4) : 275-279.

Magurran AE. 1988. Ecological Diversity and Its Measurement. London (GB) : Croom Helm Limited.

[Perum Perhutani] Direksi Perum Perhutani 2007. Keputusan Direksi Perum Perhutani No: 268/KPTS/DIR/2007 Tentang Pedoman 
Pengelolaan Hutan Bersama Masyarakat Plus (PHBM Plus). Jakarta: Perum Perhutani.

[Perum Perhutani] KPH Garut 2004. Buku Obor Biodiversitas KPH Garut. Garut: Perum Perhutani.

Purwowidodo M. 2004. Mengenal Tanah Hutan: Metode Kajian Tanah. Bogor: Laboratorium Pengaruh Hutan Fakultas Kehutanan IPB.
Setiadi. 2000. Jalur Intepretasi Potensi Ekowisata Gunung Tampomas, Kabupaten Sumedang [Skripsi]. Bogor (ID) : Fakultas Kehutanan Institut Pertanian Bogor.

Zulkarnain. 2013. Analisisl kriteria penetapan hutan. Jutnal Agro. 2 (7) : 240-243. 